\title{
THE INFLUENCE OF RATIO ANALYSIS TO THE DIVIDEND PAYOUT RATIO AND ITS IMPACT ON THE VALUE OF THE COMPANY LISTED ON THE MALAYSIA STOCK EXCHANGE
}

\author{
Rudi Sanjaya \\ Universitas Pamulang \\ rudisanjaya938@gmail.com
}

\begin{abstract}
The powerful influences to the dividend policy that indicated by the Dividend Payout Ratio (DPR) by fundamental factor. The aim of this research is to determine the impact of fundamental factor such as of Earning Per Share (EPS), Current Ratio (CR), Debt to Equity Ratio (DER) to the Dividend Payout Ratio (DPR) and its impact on corporate value is proxyed by Price Earning Ratio (PER) the oil palm plantation. This research was conducted using secondary data that obtained from www.bursamalaysia.com period 2009-2016. The method of analysis is descriptive statistics method and panel data regression method. The sample of this research was extracted with purposive sampling. The 88 corporate annual reports was analyzed as sampels. Testing hypothesis research using model fixed effect with eviews app tool 9 version. This results indicate that growth EPS, CR, DER, DPR and firm value in oil palm plantation companies in Malaysia Exchanges from 2009-2016 period on average fluctuate every year. Partially variable Earning Per Share (EPS) doesn't have a significant effect on the variable Dividend Payout Ratio (DPR). Partially the variable Current Ratio (CR) has a significant effect on the variable Dividend Payout Ratio (DPR). Partially variable Debt to Equity Ratio (DER) doesn't have significant effect on the variable Dividend Payout Ratio (DPR). Simultaneously and together the variable Earning Per Share (EPS), Current Ratio (CR), and Debt to Equity Ratio (DER) have a significant on the variable Dividend Payout Ratio (DPR). Partially variable Dividend Payout Ratio (DPR) has no significant effect on firm value variable (proxy with (PER) Price Earning Ratio).
\end{abstract}

Keywords : Earning Per share (EPS), Current Ratio (CR), Debt to Equity Ratio (DER), Dividend Pay out Ratio (DPR), the Value of the company.

\section{INTRODUCTION}

The capital market is one of the effective suggestions to accelerate development financing through collecting funds from the community and channeling these funds to productive sectors. With the development of the capital market, investment alternatives for financiers are now no longer limited to "real assets" and deposits in the banking system but can invest funds in the capital market, both in the form of stocks, bonds and other sequences.

Activity financial management in a firm covering three decision, namely: (1) an investment decision, (2) the 
resolution funding, and (3) the dividend. Each decision has the same goal in obtaining the capital gains tax and enhancing the value of the company. Dividend, a part which cannot be separated by the decision of funding and investment decisions of companies, but they often serve as a last consideration after consideration of investments and other cost considerations.

Investors can see how the development of the company from year to year through corporate financial performance information and other relevant information such as the country's economic conditions. Fundamental analysis is more appropriate because it is highly related to the financial condition of the financial company real data especially. Financial reports already published to obligatory go public general audience through the performance summary published Malaysia exchange, so investors know the performance of the company from previous years not quite profitable for invest by looking at the ratio of corporate finance in its ability to generate profitability and size of dividends. Based on the average of the development Dividend Payout Ratio over the period of 2009-2016 experienced fluctuations. Following the development of the Dividend Payout Ratio on a palm oil plantation companies that distribute dividends respectively in the period 2009-2016.

Table 1

Average Development of Dividend Payout Ratio for the 2009-2016 Period

\begin{tabular}{|c|c|c|c|c|c|c|c|c|c|}
\hline \multirow[t]{2}{*}{ No } & \multirow[t]{2}{*}{ Perusahaan } & \multicolumn{8}{|c|}{ Dividen Payout Ratio } \\
\hline & & 2009 & 2010 & 2011 & 2012 & 2013 & 2014 & 2015 & 2016 \\
\hline 1 & BLD PLANTATION BHD & 14.14 & 5.57 & 0.49 & 1.01 & 0.79 & 2.29 & 1.37 & 1.31 \\
\hline 2 & $\begin{array}{l}\text { CHIN TECK PLANTAIONS } \\
\text { BERHAD }\end{array}$ & 0.57 & 0.71 & 0.51 & 0.52 & 0.76 & 1.13 & 1.11 & 0.66 \\
\hline 3 & $\begin{array}{ll}\text { GENTING } & \text { PLANTATIONS } \\
\text { BERHAD } & \\
\end{array}$ & 0.21 & 0.19 & 0.31 & 0.23 & 2.96 & 0.21 & 0.21 & 3.71 \\
\hline 4 & GOPENG BERHAD & 0.19 & 0.19 & 1.37 & 4.53 & 0.21 & 8.31 & 0.71 & 0.25 \\
\hline 5 & $\begin{array}{lll}\text { HAP } & \text { SENG } \\
\text { BERHAD } & \\
\end{array}$ & 9.01 & 13.01 & 11.01 & 10.01 & 11 & 8.01 & 11.02 & 10.01 \\
\hline 6 & $\begin{array}{l}\text { KUALA LUMPUR KEPONG } \\
\text { BERHAD }\end{array}$ & 6.90 & 5.70 & 5.70 & 5.70 & 5.80 & 5.90 & 5.50 & 3.30 \\
\hline 7 & $\begin{array}{ll}\text { MENTIGA } & \text { CORPORATIONS } \\
\text { BERHAD } & \\
\end{array}$ & 5.41 & 12.33 & 3.68 & 3.26 & 9.24 & 0.92 & 3.33 & 5.12 \\
\hline 8 & $\begin{array}{l}\text { SARAWAK PLANTATIONS } \\
\text { BERHAD }\end{array}$ & 0.61 & 0.62 & 0.56 & 0.59 & 0.57 & 0.41 & 0.56 & 0.56 \\
\hline 9 & TDM BERHAD & 0.25 & 0.48 & 0.33 & 0.53 & 0.33 & 0.41 & 0.13 & 0.41 \\
\hline 10 & TH PLANTATIONS BERHAD & 12.75 & 18.75 & 24.92 & 9.21 & 7.34 & 4.01 & 3.21 & 12.01 \\
\hline 11 & PLANTATIONS & 12.75 & 18.75 & 24.92 & 9.21 & 7.24 & 4.01 & 3.21 & 12 \\
\hline & Rata-rata & 11.36 & 11.61 & 11.38 & 8.74 & 8.96 & 7.44 & 7.26 & 7.09 \\
\hline
\end{tabular}

Source: Malaysia Stock Exchange

Based on the identification of the problems raised, the research problems can be formulated as follows:

1. What is the effect of EPS on the DPR in oil palm plantation companies?
2. What is the influence of the CR on the DPR in oil palm plantation companies?

3. How does the DER affect the DPR in oil palm plantation companies? 
4. How does the EPS, CR and DER affect the DPR simultaneously on ?

5. What is effect of Dividend Payout Ratio on Company Values on oil palm plantation companies?

\section{LITERATURE REVIEW}

\subsection{Financial Management}

Based on statements from James and Wachowicz (Marlina \& Clara, 2009:3) financial management (financial management) pertaining to the acquisition, funding and management of assets with some general purpose and background. In addition, the same opinion also delivered by Weston and E. Copeland (Raharjo, 2009:3), understanding financial management can be deduced from the duties and responsibilities of the manager of finance, even though the duties and responsibilities vary in each the company. Financial management is all activities related to acquisition, funding and management of assets with some overarching goal (Kasmir, 2013:5).

\subsection{Financial Report}

Financial report a summary report, which is useful for users of financial statements for decision making (Wild, Larson, Chiappetta, 2007:17).
According to Kasmir (2015:7), the financial statements report of the historical achievements of a company and provide the basis, along with business analysis and economic forecasting, for projection and for the future. Financial statements portray the financial company outposts earned in one period. In practice, the three basic financial statements is known, namely the financial balance sheet, profit loss report cash flow statement.

According to Ikatan Akuntan Indonesia (2011:1.5-1.6) the objective of financial statements is providing information about the financial position, financial performance and cash flows of an entity that will benefit most among the users of the financial statements in the making economic decisions.

\subsection{Financial Ratio}

Financial ratio is an activity comparing

the figures that exist in the financial statements by means of dividing one number with another number (Kasmir, 2015:104). Each financial ratio has a purpose, usefulness and sense, then any results of the measured ratio is interpreted so that it becomes more meaningful to decision making.

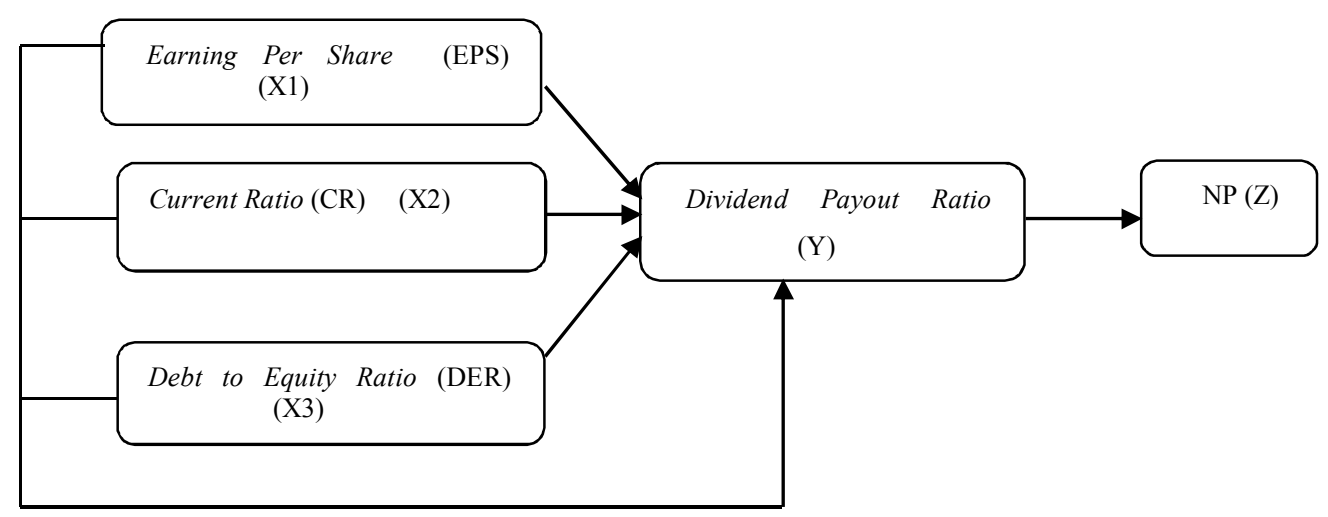

Figure 1. Research Paradigm 


\section{RESEARCH METHOD}

\subsection{Data Colection Techniques}

Secondary data are obtained in the form of the annual report and the audited financial statements the company's palm oil plantations which have been listed on Malaysia exchange in 2009-2016.

\subsection{Operational Definitions of Variables}

In this study there are five variables examined, namely the free variable (the independent) is Earning Per Share (X 1), Current Ratio (X 2), and the Debt to Equity Ratio (X 3), variable (dependent) is Dividend Payout Ratio (Y) and $(\mathrm{Z})$ variables is The value of the Company is proxyed by Price Earning Ratio.

\subsection{Sample Collection Techniques}

The sample in this research is Earning Per Share, Current Ratio, and Debt to Equity Ratio, against the Dividend Payout Ratio to the value of the company is proxyed by Price Earning Ratio at a palm oil plantation companies listed on the stock exchange Malaysia 2009 period up to 2016.
On the method of withdrawal of samples in this study is the method of withdrawal nonprobability sampling by using a purposive sample withdrawal technique is to define the specific criteria. As for the sample criteria, among others:

i. Palm oil plantations Companies listed on Bursa Malaysia in the period 2009-2016.

ii. Financial statements used are annual report (annual report) and the ringgit in units have been audited.

iii. Financial statements showing the position of profit over a period of years 2009-2016.

iv. Palm oil plantation Firm having associated data end of year stock price (closing price) and the Price Earning Ratio on investors during the period 2009-2016.

The sample in the study there were 40 samples. Based on the criteria in the above sample obtained a sample of 11 companies. the following is a list of companies that become the sample above.

Table 2

A sample list of the company's palm oil plantations in Bursa Malaysia that have complete Data Period 2009-2016

\begin{tabular}{|c|l|l|}
\hline No & Stock Code & \multicolumn{1}{c|}{ Company } \\
\hline 1 & 5069 & BLD PLANTATIONS BHD \\
\hline 2 & 1929 & CHIN TECK PLANTAIONS BERHAD \\
\hline 3 & 2291 & GENTING PLANTATIONS BERHAD \\
\hline 4 & 2135 & GOPENG BERHAD \\
\hline 5 & 5138 & HAP SENG PLANTATIONS BERHAD \\
\hline 6 & 2445 & KUALA LUMPUR KEPONG BERHAD \\
\hline 7 & 5223 & MENTIGA CORPORATIONS BERHAD \\
\hline 8 & 5135 & SARAWAK PLANTATIONS BERHAD \\
\hline 9 & 2054 & TDM BERHAD \\
\hline 10 & 5112 & TH PLANTATIONS BERHAD \\
\hline 11 & 2089 & UNITED PLANTATIONS BERHAD \\
\hline
\end{tabular}

Source : www.Bursamalaysia.com 


\subsection{Data Analysis Techniques}

a) Descriptive Statistic

Descriptive statistics can present the data in the form of a table, graph, pie charts, pictogram, the calculation mode, median, mean, calculation of the deciles, the percentile calculation, the dissemination of data through the calculation of an average and standard deviation, percentage calculation (Sugiyono, 2016: 202).

b) Testing the regression Model to the Data panel

The data panel according to Widarjono (2013:353) is the combined data of cross section and time series. Regression using data panel data regression model is called panel. The data of cross section according to Wing Revelation (2015:1.1) data is multiple objects at one time. While the data time series according to the Wing's revelation (2015:1.1) is the data of an object consisting of several periods.

According to Widarjono (2013: 252), for the estimation parameter of the models with panel data, there are three model that is often offered as follows:

1) Common Effect Model

2) The Fixed Effect Model.

3) Random Effect Model.

c) Election of the Model (the technique of estimation) Panel Data Regression.

There are three test data estimation

techniques for selecting the panel, namely:

1) Test Chow

2) Test Hausman

3) Test Lagrange Multiplier (LM)

d) Testing the classical Assumptions.

Panel data regression model provides an alternate, common effect, fixed effects and random effects.
e) Feasibility Test Data Regression Model Panel.
f) The Hypothesis Test

is used for research is a test of significance. Significance test to determine whether a hypothesis made is accepted or rejected.

\section{RESULTS AND DISCUSSIONS}

\subsection{Results}

4.1.1. Calculation of Earning Per Share, Current Ratio, Debt to Equity Ratio, Dividend Payout Ratio and the value of the company

Table 4.1 are described in the following is a table of test results from the descriptive statistics of independent variables, the dependent variable is the Dividend Payout Ratio, and its impact on the Price Earning Ratio.

\section{Table 3}

Statistical results Deskriftif independent variable

$(X) E P S, C R$, and DER (Y) the dependent

Variable and the variable $(Z)$ value of the company

\begin{tabular}{|c|c|c|c|c|c|}
\hline & EPS & $C R$ & DER & DPR & PER \\
\hline Mean & 44.68966 & 7.909852 & 0.547784 & 9.306932 & 123.9322 \\
\hline Median & 21.74500 & 3.105000 & 0.350000 & 3.085000 & 103.4300 \\
\hline Maximum & 180.0000 & 57.21000 & 3.060000 & 69.05000 & 420.2500 \\
\hline Minimum & 0.570000 & 0.410000 & 0.110000 & 0.130000 & 2.710000 \\
\hline Std. Dev. & 49.82592 & 11.29283 & 0.520633 & 16.02160 & 109.9550 \\
\hline Skewness & 1.319754 & 2.214431 & 2.206402 & 2.432846 & 0.669885 \\
\hline Kurtosis & 3.461336 & 7.699121 & 9.386740 & 7.963557 & 2.607434 \\
\hline Jarque-Bera & 26.32606 & 152.8874 & 220.9654 & 177.1435 & 7.146670 \\
\hline Probability & 0.000002 & 0.000000 & 0.000000 & 0.000000 & 0.028062 \\
\hline Sum & 3932.690 & 696.0670 & 48.20500 & 819.0100 & 10906.03 \\
\hline Sum Sq. Dev. & 215988.2 & 11094.93 & 23.58208 & 22332.18 & 1051838. \\
\hline Observations & 88 & 88 & 88 & 88 & 88 \\
\hline
\end{tabular}

Based on table 4.1 shows that in general the average mean earnings Per ratio of 11 palm oil plantations company that examined the period 2016 Fund 2009 was of 44.68966 or of $446.89 \%$ this acting on company plantations Palm oil from the year 2009 funds average 1 2016 shares by getting a net profit of 447 RM range the lowest Revenue Per value ratio in the range of 180.0000 and 0.570000 . companies that have the lowest Revenue Per ratio was $\mathrm{Tdm}$ Berhad i.e. the 0.570000 of acting 1 shares with gaining 0.57 or net profit 
RM 57, while earning the highest ratio Per is 180 that acting 1 shares with get net profit RM 180.

4.1.2. Calculation of Earning Per Share, Current Ratio, Debt to Equity Ratio, Dividend Payout Ratio and the value of the company

The model data analysis panel are :

\section{- Common Effect Test Tabel 4Common Effect Model}

Dependent Variable: LDPR

Method: Panel Least Squares

Date: 09/04/17 Time:14:11

Sample: 20092016

Periods included: 8

Cross-sections included: 11

Total panel (balanced) observations: 88

\begin{tabular}{lrlll}
\hline \hline \multicolumn{1}{c}{ Variable } & Coefficient & Std. Error & t-Statistic & Prob. \\
\hline \hline C & -0.246573 & 0.492417 & -0.500741 & 0.6179 \\
LEPS & 0.525551 & 0.128738 & 4.082325 & 0.0001 \\
LCR & -0.499841 & 0.148402 & -3.368163 & 0.0011 \\
LDER & -0.104755 & 0.231438 & -0.452626 & 0.6520 \\
\hline \hline R-squared & 0.257287 & Mean dependent var & 0.865449 \\
Adjusted R-squared & 0.230761 & S.D. dependent var & 1.782784 \\
S.E. of regression & 1.563613 & Akaike info criterion & 3.776264 \\
Sum squared resid & 205.3703 & Schwarz criterion & 3.888870 \\
Log likelihood & -162.1556 & Hannan-Quinn criter. & 3.821630 \\
F-statistic & 9.699611 & Durbin-Watson stat & 0.797830 \\
Prob(F-statistic) & 0.000015 & & &
\end{tabular}

Source: Research Data Processed, 2017 with Eviews version 9

\section{- Fixed Effect Test}

Tabel 5 Fixed Effect Model

Dependent Variable: LDPR

Method: Panel Least Squares

Date: 09j04j17 Time:14:11

Sample: 20092016

Periods included: 8

Cross-sections included: 11

Total panel (balanced) observations: 88

\begin{tabular}{crrrr}
\hline \hline Variable & Coefficient & Std. Error & t-Statistic & Prob. \\
\hline \hline C & 0.830827 & 0.401265 & 2.070520 & 0.0419 \\
LEPS & -0.082668 & 0.116301 & -0.710810 & 0.4794 \\
LCR & 0.302968 & 0.153059 & 1.979414 & 0.0515 \\
LDER & 0.086876 & 0.159325 & 0.545273 & 0.5872 \\
\hline \hline
\end{tabular}

Cross-section fixed (dummy variables)

R-squared $\quad 0.820560$ Mean dependentvar 0.865449

Adjusted R-squared $\quad 0.789036$ S.D. dependent var $\quad 1.782784$

0.818846 Akaike info criterion 2.583069

Sum squared resid $\quad 49.61768$ Schwarz criterion 2.977191

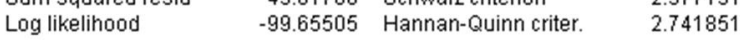

F-statistic

Prob(F-statistic)

26.03027 Durbin-Watson stat 1.979087

\section{- Random Effect Test}

Table 6 Random Effect Model

\begin{tabular}{|c|c|c|c|c|}
\hline \multicolumn{5}{|c|}{$\begin{array}{l}\text { Dependent Variable: LDPR } \\
\text { Method: Panel EQLS (Cross-section random effects) } \\
\text { Date: } 09 / 04 / 17 \text { Time: } 14: 12 \\
\text { Sample: } 20092016 \\
\text { Periods included: } 8 \\
\text { Cross-sections included: } 11 \\
\text { Total panel (balanced) obsenvations: } 88 \\
\text { Swamy and Arora estimator of component variances }\end{array}$} \\
\hline Variable & Coemcient & Std. Error & t-Statistic & Prob. \\
\hline c & 0.733597 & 0.572110 & 1.282266 & 0.2033 \\
\hline LEPS & -0.000356 & 0.111572 & -0.003188 & 0.9975 \\
\hline LCR & 0.166736 & 0.143591 & 1.161187 & 0.2489 \\
\hline LDER & 0.076025 & 0.156970 & 0.484329 & 0.6294 \\
\hline \multicolumn{5}{|c|}{ Efrects Specification } \\
\hline & & & S.D. & Rho \\
\hline Cross-section randor & & & 1.392547 & 0.7431 \\
\hline Idiosyncratic random & & & 0.818846 & 0.2569 \\
\hline \multicolumn{5}{|c|}{ Weighted Statistics } \\
\hline R-squared & 0.015251 & \multirow{5}{*}{\multicolumn{2}{|c|}{$\begin{array}{l}\text { Mean dependent var } \\
\text { S.D. dependent var } \\
\text { Sum squared resid } \\
\text { Durbin-Watson stat }\end{array}$}} & 0.176157 \\
\hline Adjusted R-squared & -0.019919 & & & 0.841553 \\
\hline S.E. of regression & 0.849893 & & & 60.67469 \\
\hline F-statistic & 0.433629 & & & 1.653077 \\
\hline $\operatorname{Prob}(\mathrm{F}$-statistic) & 0.729477 & & & \\
\hline \multicolumn{5}{|c|}{ Unweighted Statistics } \\
\hline $\begin{array}{l}\text { R-squared } \\
\text { Sum squared resid }\end{array}$ & $\begin{array}{r}-0.080013 \\
298.6382\end{array}$ & $\begin{array}{l}\text { Mean depenc } \\
\text { Durbin-Wats }\end{array}$ & $\begin{array}{l}\text { ent var } \\
\text { in stat }\end{array}$ & $\begin{array}{l}0.865449 \\
0.335858\end{array}$ \\
\hline
\end{tabular}

Source: Research Data Processed, 2017 with

Eviews version 9

- Chow Test

Tabel 7 Hasil Uji Chow

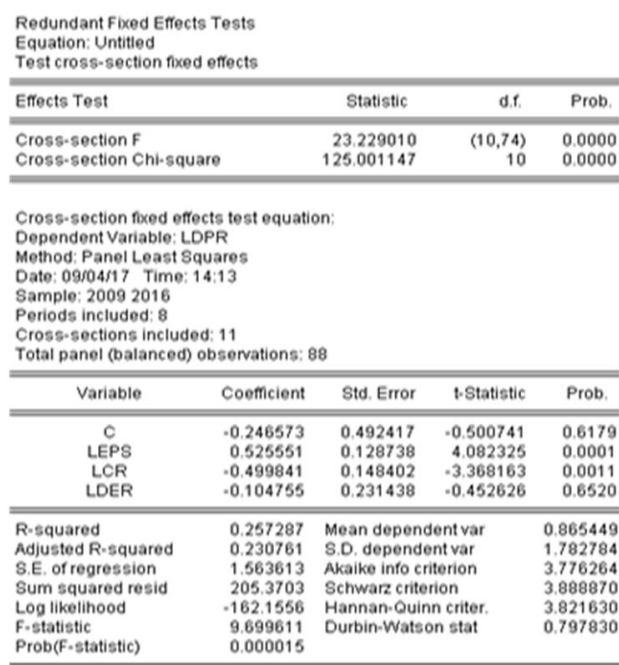

Source: Research Data Processed, 2017 with

Eviews version 9

Source: Research Data Processed, 2017 with

Eviews version 9 


\subsubsection{Analyze and Calculation}

To see the magnitude of influence Earning Per Share (EPS), Current Ratio (CR), Debt to Equity Ratio (DER) as variable independent of Dividend Payout Ratio (DPR) as the dependent variable using the Fixed Effect models.

Here is the fixed Effect models for Regression variable Earning Per Share (EPS), Current Ratio (CR), and the Debt to Equity Ratio (DER) Table 8

Regression analysis of the Data Panel Fixed Effect Model for EPS, CR, and DER Against PARLIAMENT

Dependent Variable: LDPR

Method: Panel Least Square

Date: 09/04/17 Time: 14:11

Sample: 20092016

Periods included: 8

Cross-sections included: 11

Total panel (balanced) observations: 88

\begin{tabular}{crrrr}
\hline \hline Variable & Coefficient & Std. Error & t-Statistic & Prob. \\
\hline \hline C & 0.830827 & 0.401265 & 2.070520 & 0.0419 \\
LEPS & -0.082668 & 0.116301 & -0.710810 & 0.4794 \\
LCR & 0.302968 & 0.153059 & 1.979414 & 0.0515 \\
LDER & 0.086876 & 0.159325 & 0.545273 & 0.5872 \\
\hline \hline \multicolumn{5}{c}{ Effects Specification }
\end{tabular}

Cross-section fixed (dummy variables)

\begin{tabular}{llll}
\hline R-squared & 0.820560 & Mean dependentvar & 0.865449
\end{tabular}

$\begin{array}{llll}\text { Adjusted R-squared } \quad 0.789036 & \text { S.D. dependent var } & 1.78278\end{array}$

S.E. of regression $\quad 0.818846$ Akaike info criterion 2.583069

Sum squared resid $\quad 49.61768$ Schwarz criterion $\quad 2.977191$

$\begin{array}{lrll}\text { Log likelihood } & -99.65505 & \text { Hannan-Quinn criter. } & 2.741851 \\ \text { F-stistic } & 26.03027 & \text { Durbin-Watson stat } & 1.97908\end{array}$

$\begin{array}{ll}\text { F-statistic } & 26.03027 \\ \text { Prob(F-statistic) } & 0.000000\end{array}$

Source: Research Data Processed, 2017 with Eviews version 9

Based on table 4.6 using the Fixed Effect Model has the value of the constant 0.830827 as for the regression coefficient variable Log EPS-0.082668 the coefficient variable regression of 0.302968 the coefficient CR Log regression of the $\log$ of the variable DER amounted the regression equation into 0.086876 so that:

$\mathrm{Y}=0.830827+-082668 \log$ EPS + $0.302968 \log 0.086876 \log$ DER + CR

\section{t-Test}

1. Influence of Earning Per Share (EPS) of the DPR

The test results panel data analysis in partial results showed t-count as independent variables for the following
EPS is- 0.710810 while t-table with $\alpha=$ $5 \%$ and $\mathrm{df}=(\mathrm{n}-\mathrm{k}) \square 88-4=84$, then the $\mathrm{t}$-table $=1.66320$, so t-count is less than the t-table $(-0.710810<1.66320)$, so it can be inferred that the independent variable EPS there is no effect on the dependent variable.

2. The Influence Of Current Ratio (CR) Of DPR

The test results panel data analysis in partial results showed t-count as the following independent variables for the CR is of 1.979414 while $t$-table with $\alpha=$ $5 \%$ and $\mathrm{df}=(\mathrm{n}-\mathrm{k}) \square 88-4=84$, then the $\mathrm{t}$-table $=1.66320$, so $\mathrm{t}$-count is greater than t-table $(1.979414>1.66320)$, so it can be inferred that the independent variable $C R$ there is a positive influence towards the dependent variables of the DPR. Then the probability of a value greater than the value of the $\mathrm{CR}$ constants $(0.0515>0.05)$.

3. The influence of the Debt to Equity

Ratio (DER) against the DPR

The test results panel data analysis in partial results showed $t$-calculate as follows for the independent variable DER 0.545273 is a temporary table $t$ with $\alpha=5 \%$ and $\mathrm{df}=(\mathrm{n}-\mathrm{k}) \square 88-4=84$, then the $\mathrm{t}$-table $=1.6627$, so $\mathrm{t}$-count is less than the t-table $(0.545273<$ 1.6627), so it can be inferred that the independent variable DER there is no effect on the dependent variable.

\subsection{Discussions}

H1: based on the results of hypothesis testing the influence of Earning Per Share (EPS) of Dividend Payout Ratio (DPR) acquired t-female $<$ t-table ($0.710810<1.66320$ ) with probability values (significance) $0.4794>0.05$, then $\mathrm{H} 0$ and $\mathrm{H} 1$ rejected. This shows there is no influence of the variable EPS of DPR on the company's palm oil plantations.

$\mathrm{H} 2$ : based on the results of hypothesis testing the influence of Current Ratio Dividend Payout Ratio is obtained against $\mathrm{t}$-female $>\mathrm{t}$-table $(1.979414>$ 1.66320) with probability values 
(significance) $0.0515>0.05$, then $\mathrm{H} 0$ and $\mathrm{H} 1$ accepted rejected. This shows there is a significant and positive influence of the variable Current Ratio (CR) against a Dividend Payout Ratio (DPR) on the company's palm oil plantations.

H3: based on the results of hypothesis testing the influence of Debt to Equity Ratio (DER) against the Dividend Payout Ratio obtained t-female $<\mathrm{t}$-table $(0.545273<1.6627)$ with probability values (significance) $0.5872>0.05$, then $\mathrm{H} 0$ and $\mathrm{H} 1$ accepted rejected. This shows there is no significant effect of variable DER against DPR on the company's palm oil plantations, the positive Sign is indicated by the value of the variable's Debt to Equity Ratio, this means that the Debt to Equity Ratio and the Dividend Payout Ratio has a direct relationship.

H4: based on the results of hypothesis testing the influence of EPS, CR, and DER against DPR obtained t-female $<\mathrm{t}$ table $(26.03027>2.48)$ and smaller probability values of constants $(0.0000$ $<0.05)$, then it can be expressed simultaneously there is influence significantly to Dividend Payout Ratio (DPR). The magnitude of R-Square (R2) is of 0.820560 then it could be interpreted that the sample can be represent to total population of 82.05 . This can mean that the sample in this regression is capable of representing a total population of approximately $82.05 \% 17.95 \%$ while the rest are influenced other factors from outside the regression model.

\section{REFERENCES}

, (2015), Bursa Malaysia, In Malaysia Online: Malaysia [Online]. Tersedia: http://www.bursamalaysia.com/ market/ [25 April 2015]
H5: based on results of testing hypotheses variable Dividend Payout Ratio (DPR) has a negative impact and there is no significant results of the Eviews retrieved value $t$-female is smaller than the t-table $(0.536395<$ 1.6627) and with a value of the HOUSE is larger than the probability of the value of the constants $(0.5933<0.05)$, hence $\mathrm{H} 0$ and H1 rejected, accepted so Dividend Payout Ratio of free variables there is no influence of significance against the variable bound to a variable the value of the company on the company's coconut Palm oil in Malaysia in the period 2009-2016.

\section{CONCLUSIONS}

After performing data processing with the help of software Eviews 9 then it can be known to be the result of testing and discussion in this research so that it can be summed up as follows:

1. Partially ratio of EPS there are no significant influence and against DPR.

2. CR is significant influence and against DPR.

3. There are no significant influence between DER and against DPR.

4. Simultaneously the ratio of Earning Per Share (EPS), Current Ratio (CR), and the Debt to Equity Ratio (DER) there is significant influence and against DPR.

5. There is no influence and significantly of DPR to the value of the company. 
, (2015), Malaysia Stock

Market, In Malaysia Online:

Malaysia [Online]. Tersedia: https://www.malaysiastock.biz/L atest-Announcement.aspx/ [20 Maret 2015]

Horne, J. C. V. dan Wachowicz, J. M., (2009), Fundamental of Financial Management, Jakarta, Salemba Empat.

Ikatan Akuntansi Indonesia, 2011, PSAK ( Pernyataan Akuntansi Keuangan), Edisi Kedelapan, Salemba Empat, Jakarta.

Imran, Khasif, (2011), Determinants of Dividend Payout Policy, A Case of Pakistan Engineering Sector, University of Karachi.

Kasmir, (2016), Analisis Laporan Keuangan, PT Raja Grafindo Persada, Jakarta

Marlina, Lisa dan Clara Danika (2009), Analisis Pengaruh Cash Position, Debt to Equity Ratio, dan Return On Assets Terhadap Dividend Payout Ratio, Jurnal Manajemen Bisnis, Volume 2 No.1 Hal 1-6. Universitas Sumatra Utara.

Nur, Diana, (2012), Pengaruh Kinerja Keuangan Terhadap Kebijakan Deviden pada Industri Barang Konsumsi yang Terdaftar Di Bursa Eek Indonesia, Fakultas Ekonomi, Universitas Gunadarma.

Raharjo, Budi, (2009), Laporan Keuangan Perusahaan, UGM Press, Yogyakarta.
Rahayuningtyas, S, Suhandak, dan Handayani, S,R, (2014), "Pengaruh Rasio-Rasio Keuangan Terhadap Dividend Payout Ratio (DPR), (Studi Pada Perusahaan Yang Listing Di BEI Tahun 2009-2011). Fakultas Ilmu Administrasi, Universitas Brawijaya Malang.

Sriyana, J, (2014), Metode Regresi Data Panel, Ekonisia, Yogyakarta.

Sugiyono, (2016), Metode Penelitian Kuantitatif, Kualitatif, Dan Kombinasi (MIXED METHODS), Cetakan Ke-8, Penerbit Alfabeta, Bandung.

Sumiadji, (2011), Analisis Variabel Keuangan yang Mempengaruhi Kebijakan Deviden pada Perusahaan Manufaktur yang Terdaftar Di Bursa Efek Indonesia Periode 2004-2008", Jurnal Dinamika Akuntansi, Volume 3 No. 2 Hal 129-138, Poloteknik Negeri Malang, Malang

Widarjono, A., 2007, Ekonometrika Teori dan Aplikasi untuk Ekonomi dan Bisnis", Ekonisia, Yogyakarta.

Wild, Larson, Chiappetta, (2007), Financial and Managerial Accounting, International Edition, Mc-Graw-Hill, Singapore.

Winarno, W. W., (2015), Analisis Ekonometrika dan Statistika dangan Eviews, UPP STIM YKPN, Yogyakarta. 